\title{
Potential rates and environmental controls of anaerobic ammonium oxidation in estuarine sediments
}

\author{
Catarina Teixeira ${ }^{1,2, *}$, Catarina Magalhães ${ }^{2}$, Samantha B. Joye ${ }^{3}$, \\ Adriano A. Bordalo ${ }^{1,2}$ \\ ${ }^{1}$ Laboratory of Hydrobiology, Institute of Biomedical Sciences (ICBAS-UP), University of Porto, \\ Rua Jorge Viterbo Ferreira 228, 4050-313 Porto, Portugal \\ ${ }^{2}$ Interdisciplinary Centre for Marine and Environmental Research (CIIMAR-UP), Rua dos Bragas, no 289, 4050-123 Porto, \\ Portugal \\ ${ }^{3}$ Department of Marine Sciences, The University of Georgia, Athens, Georgia 30602-3636, USA
}

\begin{abstract}
The importance of anaerobic ammonium oxidation (anammox) - a metabolic pathway that can generate dinitrogen - remains poorly described in temperate estuarine systems. We evaluated the relative importance of anammox and denitrification along the salinity gradient of the Cávado River estuary (NW Portugal) during a seasonal survey. Potential rates of anammox and denitrification were measured in anaerobic sediment slurries using ${ }^{15} \mathrm{~N}$-labeled $\mathrm{NO}_{3}{ }^{-}$and $\mathrm{NH}_{4}{ }^{+}$ amendments. Production of ${ }^{29} \mathrm{~N}_{2}$ and ${ }^{30} \mathrm{~N}_{2}$ in the slurries was quantified using membrane inlet mass spectrometry (MIMS). Environmental parameters such as salinity, temperature and inorganic nitrogen were also monitored. Anammox and denitrification potentials in Cávado estuarine sediments varied from 0 to 3.3 and from 1.1 to $10.8 \mathrm{nmol} \mathrm{N} \mathrm{cm}^{-3}$ wet sediment $\mathrm{h}^{-1}$, respectively. During 1 sampling occasion, anammox activity accounted for as much as $72 \%$ of the measured production of dinitrogen, while annual averages varied from 17 to $33 \%$ depending on location. Nitrate availability and temperature appeared to be the primary environmental controls of anammox. Higher concentrations of $\mathrm{NO}_{3}^{-}$and intermediate temperatures in the estuarine water (14 to $16^{\circ} \mathrm{C}$ ) supported higher anammox activities. Using 16S rRNA gene-specific primers, anammox-like bacterial sequences were recovered from Cávado sediments - corroborating the measured anammox activities. Our results support the environmental importance of anammox for removal of nitrogen in estuarine sediments, and suggest that this process is apparently regulated by few variables.
\end{abstract}

KEY WORDS: Anammox $\cdot$ Denitrification $\cdot$ Sediments $\cdot$ Estuary

\section{INTRODUCTION}

Microbial nitrogen cycling plays an important role in the maintenance of the biosphere (Gruber \& Galloway 2008). In the last $100 \mathrm{yr}$, our perception of the nitrogen cycle has shifted from its role in promoting agricultural crop yields to an increasing awareness of the consequences of human interference (Galloway et al. 2008). Worldwide, the amount of soluble nitrogenous compounds entering estuaries and coastal waters from land, rivers and the atmosphere has increased dramatically in recent decades (Gruber \& Galloway 2008). The anthropogenic influence on the global nitrogen cycle has contributed to a suite of environmental problems, such as the decrease in forest and grassland productivity and global climate change (Galloway et al. 2003). Also, the human disturbance of nitrogen fluxes may ag- 
gravate coastal eutrophication problems (Fulweiler et al. 2007).

Until recently, denitrification was thought to be the only major pathway that forms dinitrogen in the environment and removes inorganic nitrogen from aquatic systems (Herbert 1999). This process has been investigated thoroughly, revealing that a large fraction of the external nitrogen load delivered to coastal ecosystems is removed via sediment denitrification (e.g. Seitzinger et al. 2006), thereby reducing both anthropogenic eutrophication and nitrogen pollution of the open ocean (Seitzinger et al. 2006).

Indications that an ammonium oxidation pathway occurs in anoxic environments have appeared occasionally in the literature since 1941 (Hamm \& Thompson 1941, Dalsgaard et al. 2005 and references therein). However, only in the 1990s was the process demonstrated to occur on wastewater sludge in a denitrifying reactor (Mulder et al. 1995). Later on, Thamdrup \& Dalsgaard (2002) provided evidence of anammox activity in natural habitats, adding to our understanding of the biological nitrogen cycle. Anammox - anaerobic ammonium oxidation - uses nitrite as an electron acceptor, producing dinitrogen as the final product (van de Graaf et al. 1995). The process is mediated by obligatory anaerobic chemolithotrophic bacteria identified as members of the Planctomycetes (Strous et al. 1999). Anammox contributes significantly to dinitrogen production in the ocean, being recognized as a major sink for fixed inorganic nitrogen in anoxic water basins (Dalsgaard et al. 2003, Kuypers et al. 2005, Lam et al. 2009) and marine sediments, accounting for as much as $79 \%$ of dinitrogen production in continental shelf sediments (Thamdrup \& Dalsgaard 2002, Engström et al. 2005). The fate of excess nitrogen in estuaries is determined by the activity of denitrifiers and anammox bacteria, although the relative importance of the 2 processes - anammox and denitrification - is still unclear, with anammox rates so far reported to account for between 0 and $30 \%$ of the measured production of dinitrogen (Trimmer et al. 2003, Risgaard-Petersen et al. 2004, Rich et al. 2008, Dale et al. 2009, Dong et al. 2009, Nicholls \& Trimmer 2009). Differences in the relative importance of denitrification and anammox may be controlled by the environmental variables that favor one process over the other.

The environmental factors that control rates of denitrification have been investigated in some detail (e.g. Cornwell et al. 1999, Magalhães et al. 2005a, Jensen et al. 2009). Nitrate (Christensen et al. 1990), organic carbon (Nixon 1981, van Luijn et al. 1999), and the activity of both benthic fauna and flora (Rys- gaard et al. 1995, Cornwell et al. 1999) are among the most important controlling factors of denitrification so far identified.

However, information on the regulation of anammox in aquatic systems is scarce. Four main factors were previously reported to regulate anammox in aquatic sediments: temperature (Dalsgaard \& Thamdrup 2002, Rysgaard et al. 2004), concentration of $\mathrm{NO}_{3}{ }^{-}$in the water (Trimmer et al. 2003, RisgaardPetersen et al. 2004, Rysgaard et al. 2004, Rich et al. 2008, Nicholls \& Trimmer 2009), concentration of $\mathrm{NO}_{2}{ }^{-}$in sediment (Meyer et al. 2005), and the content of organic carbon (Trimmer et al. 2003, Nicholls \& Trimmer 2009).

In this study, we evaluated the spatial and temporal variation of anammox and denitrification along the Cávado River estuary and focused on identifying the environmental factors that regulate differences in the levels of anammox and the relative contribution of anammox to the production of dinitrogen.

\section{MATERIALS AND METHODS}

\section{Study area and sampling}

Sediment samples were collected from 3 intertidal sites at low tide along the salinity gradient in the Cávado River estuary (NW Portugal) (Fig. 1) in August and November 2007, and in January and April 2008. The Cávado River is $135 \mathrm{~km}$ in length with a watershed of $16000 \mathrm{~km}^{2}$; it flows at an average rate of $66 \mathrm{~m}^{3} \mathrm{~s}^{-1}$ into the Atlantic Ocean at $41.54^{\circ} \mathrm{N}$, $8.79^{\circ} \mathrm{W}$. The Cávado estuary spreads over $2.56 \mathrm{~km}^{2}$ and experiences a semidiurnal mesotidal regime $(0.2$ to $3.9 \mathrm{~m}$ ). Freshwater nitrate inputs have ranged from 45 to $141 \mu \mathrm{M}$ over the past $20 \mathrm{yr}$ (annual mean values collected from the National Information System of Water Resources; INAG 2010). At each sampling site, a total of 10 sediment cores $(3 \mathrm{~cm}$ diameter, $5 \mathrm{~cm}$ deep) were collected, combined, homogenized, and stored in sterile plastic bags. Pore-water samples were drawn using a pore-water 'sipper' with a perforated ending (Ø 1 to $2 \mathrm{~mm}$ holes) inserted to a depth of $5 \mathrm{~cm}$ and attached to a Teflon sampling tube; suction was provided by a hand-operated vacuum pump. Estuarine water was also collected at each site and stored in acid-cleaned polyethylene bottles. The water column temperature and salinity were measured in situ using a portable probe (YSI, model 30). Sediment oxidation-reduction potential (Eh) within the $5 \mathrm{~cm}$ depth was measured in situ using a platinum electrode (Hanna Instruments). The electrode 


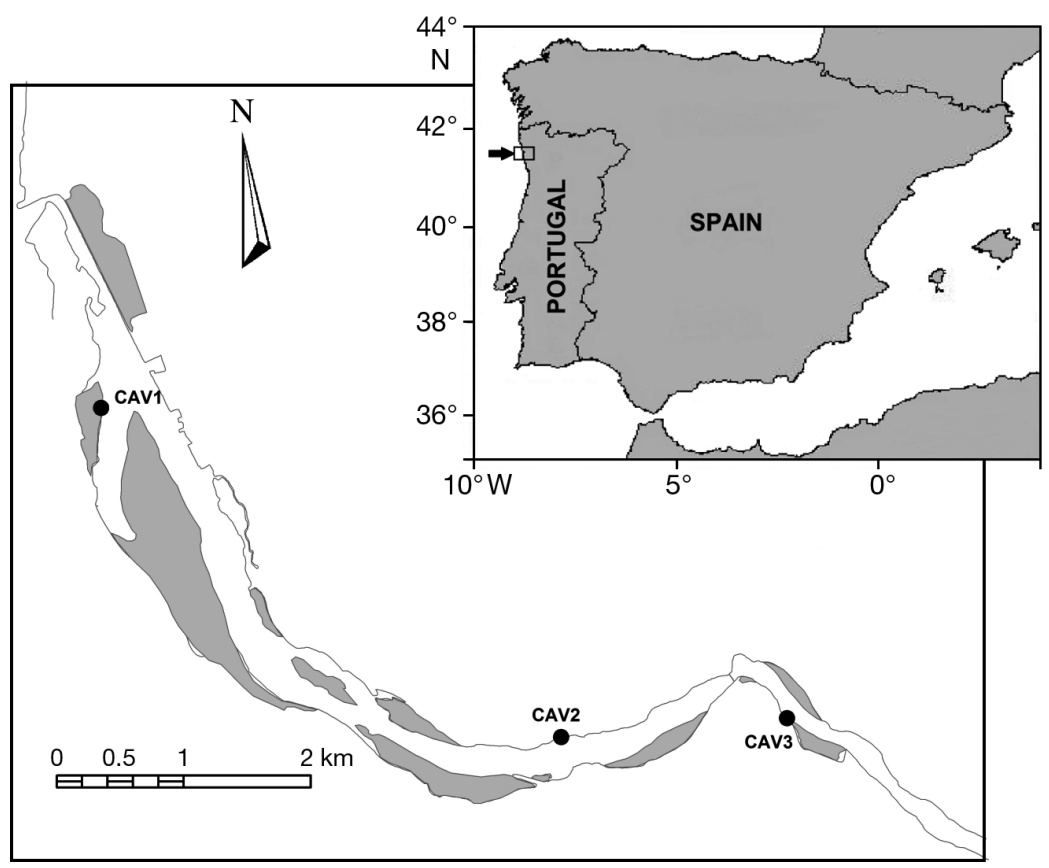

Fig. 1. Sampling sites in the Cávado River estuary, NW Portugal perature catalytic oxidation with a TOC- $\mathrm{V}_{\mathrm{CSN}}$ analyzer coupled to a total nitrogen-measuring unit (Shimadzu Instruments) according to Magalhães et al. (2008).

\section{${ }^{15} \mathrm{~N}$ sediment incubations and analysis}

Potential anammox and denitrification activities were assessed in endpoint experiments, following the procedures of Risgaard-Petersen et al. (2004), with some modifications. For each homogenized sample and treatment, 3 replicates of $5 \mathrm{ml}$ of sediment were transferred to Hungate glass tubes (Bellco Glass) with a cut-bottom fitted with rubber stoppers; the tubes were flushed with argon. Ten milliliters of Ar-purged estuarine water was regularly checked using a standard redox solution (HI7030, Hanna Instruments). Samples were immediately stored in a dark cooler and transported to the laboratory. In the laboratory, subsamples of sediment were separated and stored at $-70^{\circ} \mathrm{C}$ for extraction of DNA. The estuarine water and porewater from each site was immediately filtered $(0.45 \mu \mathrm{m})$, and samples were processed according to the analytical and incubation procedures described below.

\section{Analytical procedures}

Concentrations of nitrite $\left(\mathrm{NO}_{2}^{-}\right)$and ammonium $\left(\mathrm{NH}_{4}{ }^{+}\right)$in estuarine water and pore-water were determined colorimetrically using methods described in Grasshoff et al. (1983). Nitrate $\left(\mathrm{NO}_{3}{ }^{-}\right)$was assayed using an adaptation of the spongy cadmium reduction technique (Jones 1984). All the analyses were performed in triplicate, and standard curves were generated each day. The detection limit for $\mathrm{NH}_{4}{ }^{+}$, $\mathrm{NO}_{2}{ }^{-}$and $\mathrm{NO}_{3}{ }^{-}$was $0.1,0.02$ and $0.3 \mu \mathrm{M}$, respectively; the precision of all determinations was between 0.1 and $8 \%$, depending on the particular nutrient concentration. Sediment organic matter (OM) was measured as a percentage of weight loss on ignition $\left(500^{\circ} \mathrm{C}, 4 \mathrm{~h}\right)$. Grain size analysis was performed by dry sieving (Percival \& Lindsay 1997). Determination of dissolved organic carbon (DOC) and total nitrogen (TN) was performed by high-tem- were added, and the tubes were sealed, without headspace, using gas-tight caps with a septum. There were 3 treatments for each sample: (1) unamended control, (2) addition of $50 \mu \mathrm{M} \mathrm{K}^{15} \mathrm{NO}_{3}{ }^{-}$ (>98\% ${ }^{15} \mathrm{~N}$ atom, Isotec), and (3) addition of $5 \mu \mathrm{M}$ ${ }^{15} \mathrm{NH}_{4}{ }^{+}\left(>98 \%{ }^{15} \mathrm{~N}\right.$ atom, Isotec). ${ }^{14} \mathrm{NO}_{3}{ }^{-}$and ${ }^{14} \mathrm{NH}_{4}{ }^{+}$ were supplied by the site water. One extra set of triplicate slurries (time zero) was 'killed' immediately by injection of $200 \mu \mathrm{l}$ of a $7 \mathrm{M} \mathrm{ZnCl}_{2}$ solution. Isotope solutions were added through the septum to the amended tubes. Slurries were incubated, in the dark, at in situ temperature $\left(24,16,11\right.$ and $14^{\circ} \mathrm{C}$ for August, November, January and April campaigns, respectively). After $6 \mathrm{~h}$, biological activity was stopped by the addition of $\mathrm{ZnCl}_{2}(200 \mu \mathrm{l}, 7 \mathrm{M})$. A $4 \mathrm{ml}$ supernatant sub-sample was collected, immediately filtered $(0.45 \mu \mathrm{m})$, and stored frozen for subsequent determination of $\mathrm{NO}_{3}{ }^{-}, \mathrm{NO}_{2}{ }^{-}$and $\mathrm{NH}_{4}{ }^{+}$. The abundance of ${ }^{29} \mathrm{~N}_{2}$ and ${ }^{30} \mathrm{~N}_{2}$ was measured directly in the sediment slurry using a membrane inlet mass spectrometer (MIMS; Kana et al. 1994) consisting of a quadrupole mass spectrometer (QMS422, PfeifferBalzers) and fitted with a heated copper reduction column (Eyre et al. 2002). Relative levels of anammox and denitrification activities were calculated from the production of ${ }^{29} \mathrm{~N}_{2}$ and ${ }^{30} \mathrm{~N}_{2}$ in the samples amended with ${ }^{15} \mathrm{NO}_{3}{ }^{-}$using the equations of Thamdrup \& Dalsgaard (2002). The isotopic dilution of the added ${ }^{15} \mathrm{~N}$ tracer was calculated from the ambient concentrations of $\mathrm{NO}_{3}{ }^{-}$and $\mathrm{NH}_{4}{ }^{+}$measured in the 'killed' controls and the amount of added ${ }^{15} \mathrm{~N}$ species. ${ }^{15} \mathrm{~N}$ 
labeling varied from 32 to $65 \%$ of the nitrate pool, and from 4 to $16 \%$ of the ammonium pool. Linearity of the denitrification process during the incubation period was assessed in a previous time-series experiment using the acetylene blockage technique (data not shown).

\section{Molecular techniques}

Total community DNA was extracted from $1 \mathrm{~g}$ wet wt of sediment using a Power Soil DNA isolation kit (MoBio Laboratories), following the manufacturer's instructions. A nested PCR approach was used to detect anammox bacterial 16S rRNA gene sequences in these sediments. In the first PCR we amplified Planctomycetales-specific 16S rRNA genes by using the Pla46 primer (Neef et al. 1998) and the 1392r universal bacterial primer (Muyzer et al. 1993). DNA amplification was performed using Ready-to-Go PCR beads (GE Healthcare) in reactions containing $1 \mu \mathrm{l}$ of template DNA (5 to $15 \mathrm{ng}$ ) and $20 \mathrm{pmol}$ of each primer in a final volume of $25 \mu$ l. All PCRs were performed with initial denaturation at $94^{\circ} \mathrm{C}$ for $4 \mathrm{~min}$, followed by 40 cycles consisting of $94^{\circ} \mathrm{C}$ for $45 \mathrm{~s}, 59^{\circ} \mathrm{C}$ for $50 \mathrm{~s}$, and $72^{\circ} \mathrm{C}$ for $3 \mathrm{~min}$, with a final extension at $72^{\circ} \mathrm{C}$ for $5 \mathrm{~min}$. The second PCR was performed with the anammoxspecific 16S rRNA gene set of primers Amx 368F (Schmid et al. 2003) and Amx 820R (Schmid et al. 2000), with $1 \mu$ l of product from the first PCR reaction as template. Conditions for the second PCR were the same as those used for the first PCR, except that we used a $1 \mathrm{~min}$ extension at $72^{\circ} \mathrm{C}$ (Rich et al. 2008). PCR products were examined in $1.5 \%$ agarose gels by electrophoresis, and bands of the correct size were extracted and purified with the GFX PCR DNA and Gel Band purification kit (GE Healthcare). The amplicons were cloned using the TOPO TA cloning kit (Invitrogen). Plasmid-DNA was isolated using the GeneElute plasmid miniprep kit (Sigma). Clones were sequenced at STABVIDA Sequencing Facilities (Lisbon, Portugal). Sequences of the 16S rDNA inserts were determined by using M13 forward and reverse primers targeting vector sequences adjacent to the multiple cloning site. All sequences were compared to reference sequences from GenBank using the basic local alignment search tool (BLAST; Altschul et al. 1990). Sequences were aligned with Clustal W (Thompson et al. 1994) as implemented in Bioedit version 7.0.5 (Hall 1999). Neighbor-joining phylogenetic trees with bootstrapping were produced using MEGA software package version 5.0 (Tamura et al. 2011). Anammox bacteriarelated sequences were published in GenBank under accession numbers JF797322 to JF797330.

\section{Data analysis}

Before statistical analysis was carried out, environmental data were tested for normality and homogeneity of variances. Temporal and spatial differences were examined using 1-way analysis of variance (1way ANOVA) followed by a post hoc Tukey honestly significant difference (HSD) multi-comparison test. ANOVA and correlation analysis were performed using the software STATISTICA 6.0 (StatSoft). The significance level used for all tests was 0.05 .

\section{RESULTS}

\section{Water and sediment characteristics}

Measured water, pore-water and sediment variables are summarized in Table 1. Nitrate, nitrite, DOC and TN concentrations correlated negatively with water salinity $(\mathrm{r}=-0.67,-0.74,-0.69$ and -0.66 , respectively; $\mathrm{p}<0.05, \mathrm{n}=12$ ), showing a longitudinal gradient of nutrients being supplied by the influx of freshwater. Cávado estuary sediments were composed mainly of gravel and coarse sand with a low content of organic matter (Table 1). The content of organic matter was higher in downstream sediments and correlated with salinity $(\mathrm{r}=0.80, \mathrm{p}<0.01)$. Measurements of sediment redox potential showed that anoxic conditions were present occasionally.

\section{${ }^{15} \mathrm{~N}$ experiments}

Slurry ${ }^{29} \mathrm{~N}_{2}$ and ${ }^{30} \mathrm{~N}_{2}$ production was quantified as the end point concentration minus the background. In incubations with added ${ }^{15} \mathrm{NO}_{3}{ }^{-}$, the production of ${ }^{29} \mathrm{~N}_{2}$ and ${ }^{30} \mathrm{~N}_{2}$ was detected in sediments from all locations (Table 2). The addition of ${ }^{15} \mathrm{NH}_{4}{ }^{+}$in the presence of ambient ${ }^{14} \mathrm{NO}_{3}{ }^{-}$and ${ }^{14} \mathrm{NO}_{2}{ }^{-}$produced ${ }^{29} \mathrm{~N}_{2}$ in sediments from sites CAV2 and CAV3. At the CAV1 site, during the first 3 surveys, the occurrence of anammox activity was not supported by the ${ }^{15} \mathrm{NH}_{4}{ }^{+}$ incubations as no ${ }^{29} \mathrm{~N}_{2}$ production was detected. However, the production of ${ }^{29} \mathrm{~N}_{2}$ in our slurries might have been limited by the low ${ }^{15} \mathrm{~N}$ labeling of the $\mathrm{NH}_{4}{ }^{+}$ pool. No significant $(p>0.05){ }^{30} \mathrm{~N}_{2}$ production was noted in the presence of ${ }^{15} \mathrm{NH}_{4}{ }^{+}$(Table 2). 
Table 1. Water column, pore-water and sediment characteristics at the 3 sampling sites (CAV1, CAV2, CAV3; Fig. 1) in the Cávado River estuary (NW Portugal). $T=$ temperature; Sal $=$ salinity; DOC $=$ dissolved organic carbon; $\mathrm{TN}=$ total nitrogen; $\mathrm{OM}=$ organic matter $;$ Eh: redox potential $;$ nd = not determined

\begin{tabular}{|c|c|c|c|c|c|c|c|c|c|c|c|c|c|c|c|c|}
\hline \multirow{2}{*}{$\begin{array}{l}\text { Site } \\
\text { Date }\end{array}$} & \multirow{2}{*}{$\begin{array}{c}T \\
\left({ }^{\circ} \mathrm{C}\right)\end{array}$} & \multirow[b]{2}{*}{ Sal } & \multicolumn{5}{|c|}{ Water column } & \multirow[b]{2}{*}{ Sal } & \multicolumn{3}{|c|}{-Pore-water } & \multirow[b]{2}{*}{$\begin{array}{l}\mathrm{DOC} \\
(\mathrm{mg} / \mathrm{l})\end{array}$} & \multirow[b]{2}{*}{$\begin{array}{c}\mathrm{TN} \\
(\mathrm{mg} / \mathrm{l})\end{array}$} & \multicolumn{2}{|r|}{-Sediment } & \multirow[b]{2}{*}{$\begin{array}{c}\text { Eh } \\
(\mathrm{mV})\end{array}$} \\
\hline & & & $\begin{array}{l}\mathrm{NO}_{3}^{-} \\
(\mu \mathrm{M})\end{array}$ & $\begin{array}{l}\mathrm{NO}_{2}^{-} \\
(\mu \mathrm{M})\end{array}$ & $\begin{array}{l}\mathrm{NH}_{4}^{+} \\
(\mu \mathrm{M})\end{array}$ & $\begin{array}{l}\mathrm{DOC} \\
(\mathrm{mg} / \mathrm{l})\end{array}$ & $\begin{array}{c}\mathrm{TN} \\
(\mathrm{mg} / \mathrm{l})\end{array}$ & & $\begin{array}{l}\mathrm{NO}_{3}^{-} \\
(\mu \mathrm{M})\end{array}$ & $\begin{array}{l}\mathrm{NO}_{2}^{-} \\
(\mu \mathrm{M})\end{array}$ & $\begin{array}{l}\mathrm{NH}_{4}^{+} \\
(\mu \mathrm{M})\end{array}$ & & & $\begin{array}{l}\mathrm{OM} \\
(\%)\end{array}$ & $\begin{array}{l}\text { Grain size } \\
(<63 \mu \mathrm{m}, \%)\end{array}$ & \\
\hline \multicolumn{17}{|l|}{ CAV1 } \\
\hline Aug 07 & 21.3 & 20.9 & 21.7 & 0.5 & 3.9 & 0.60 & 0.49 & 28.9 & 2.08 & 0.70 & 29.40 & 30.79 & 0.94 & 2.2 & 11.4 & -60 \\
\hline Nov 07 & 15.5 & 20.3 & 31.1 & 0.6 & 6.8 & 0.85 & 0.72 & n.d. & 7.34 & 1.50 & 7.30 & 27.88 & 1.29 & 1.9 & 8.1 & -93 \\
\hline Jan 08 & 13.7 & 15.6 & 40.0 & 0.6 & 16.4 & 1.61 & 1.42 & 32.7 & 35.61 & 0.93 & 0.83 & 25.17 & 0.68 & 1.3 & 3.5 & 245 \\
\hline Apr 08 & 16.8 & 6.6 & 70.3 & 0.8 & 15.0 & 1.46 & 1.59 & 27.2 & 25.50 & 0.11 & 0.88 & 25.23 & 0.72 & 0.8 & 2.1 & -30 \\
\hline \multicolumn{17}{|l|}{ CAV2 } \\
\hline Aug 07 & 22.7 & 4.4 & 46.2 & 0.9 & 4.1 & 0.82 & 0.92 & 8.0 & 27.29 & 0.15 & 2.81 & 12.32 & 1.39 & 0.8 & 0.9 & 190 \\
\hline Nov 07 & 13.3 & 4.6 & 50.6 & 1.5 & 15.9 & 1.43 & 1.07 & 7.9 & 49.36 & 0.16 & 2.01 & 11.48 & 1.33 & 0.5 & 0.3 & 104 \\
\hline Jan 08 & 11.7 & 2.0 & 97.5 & 1.6 & 37.0 & 1.89 & 2.24 & 5.0 & 144.19 & 0.11 & 1.45 & 9.90 & 2.39 & 0.9 & 0.3 & 272 \\
\hline Apr 08 & 16.0 & 0.2 & 124.7 & 1.3 & 19.8 & 1.14 & 2.27 & 1.7 & 178.51 & 0.06 & 1.57 & 4.81 & 2.12 & 0.6 & 0.4 & 150 \\
\hline \multicolumn{17}{|l|}{ CAV3 } \\
\hline Aug 07 & 23.6 & 0.4 & 74.9 & 2.4 & 14.0 & 2.16 & 1.21 & 2.4 & 38.43 & 0.35 & 2.96 & 6.64 & 0.98 & 0.7 & 0.8 & 73 \\
\hline Nov 07 & 13.6 & 0.8 & 206.0 & 2.0 & 19.7 & 1.69 & 1.18 & 3.2 & 81.67 & 0.16 & 1.32 & 8.25 & 1.59 & 0.8 & 0.7 & 120 \\
\hline Jan 08 & 12.1 & 0.4 & 114.3 & 1.8 & 41.8 & 1.85 & 2.30 & 19.1 & 159.44 & 0.21 & 1.95 & nd & nd & 1.4 & 1.0 & 260 \\
\hline Apr 08 & 16.1 & 0.1 & 83.9 & 0.9 & 17.1 & 1.47 & 1.73 & 0.6 & 47.35 & 1.02 & 24.73 & nd & nd & 1.0 & 1.3 & -62 \\
\hline
\end{tabular}

Table 2. Production of ${ }^{29} \mathrm{~N}_{2}$ and ${ }^{30} \mathrm{~N}_{2}\left(\mathrm{nmol} \mathrm{cm}^{-3}\right)$ in the slurries after incubation with ${ }^{15} \mathrm{~N}$-labeled $\mathrm{NO}_{3}{ }^{-}$or with $\mathrm{NH}_{4}{ }^{+}$in the presence of ambient ${ }^{14} \mathrm{NO}_{3}{ }^{-}$. Values are averages $\pm \mathrm{SE}(\mathrm{n}=3)$. ra $\%=$ relative contribution of anammox to dinitrogen production. CAV1, CAV2 and CAV3 are sites in the Cávado River estuary, NW Portugal (see Fig. 1). nd = not determined

\begin{tabular}{|c|c|c|c|c|c|}
\hline \multirow{2}{*}{$\begin{array}{l}\text { Site } \\
\text { Date }\end{array}$} & \multicolumn{2}{|c|}{${ }^{15} \mathrm{NO}_{3}{ }^{-}$} & \multicolumn{2}{|c|}{$-{ }^{15} \mathrm{NH}_{4}{ }^{+}$} & \multirow{2}{*}{ ra \% ${ }^{\mathrm{a}}$} \\
\hline & ${ }^{29} \mathrm{~N}_{2}$ & ${ }^{30} \mathrm{~N}_{2}$ & ${ }^{29} \mathrm{~N}_{2}$ & ${ }^{30} \mathrm{~N}_{2}$ & \\
\hline \multicolumn{6}{|l|}{ CAV1 } \\
\hline Aug 07 & $7.3 \pm 0.0$ & $5.2 \pm 0.1$ & $-0.11 \pm 0.03$ & $-0.03 \pm 0.00$ & nd \\
\hline Nov 07 & $9.7 \pm 0.2$ & $7.9 \pm 0.1$ & $-0.20 \pm 0.05$ & $0.01 \pm 0.00$ & $8.2 \pm 0.6$ \\
\hline Jan 08 & $10.7 \pm 1.2$ & $3.3 \pm 0.2$ & $-0.22 \pm 0.15$ & $-0.02 \pm 0.00$ & $20.5 \pm 7.0$ \\
\hline Apr 08 & $9.3 \pm 0.3$ & $2.4 \pm 0.1$ & $0.46 \pm 0.05$ & $0.01 \pm 0.00$ & $38.1 \pm 1.4$ \\
\hline \multicolumn{6}{|l|}{ CAV2 } \\
\hline Aug 07 & $18.6 \pm 0.6$ & $5.9 \pm 0.2$ & $0.31 \pm 0.19$ & $0.00 \pm 0.00$ & $7.7 \pm 1.7$ \\
\hline Nov 07 & $20.6 \pm 1.0$ & $6.5 \pm 0.3$ & $0.85 \pm 0.39$ & $0.01 \pm 0.00$ & $16.4 \pm 3.1$ \\
\hline Jan 08 & $6.6 \pm 0.3$ & $1.1 \pm 0.1$ & $0.14 \pm 0.06$ & $-0.08 \pm 0.00$ & $34.4 \pm 2.3$ \\
\hline Apr 08 & $4.9 \pm 0.1$ & $0.4 \pm 0.0$ & $0.58 \pm 0.05$ & $-0.10 \pm 0.00$ & $71.9 \pm 1.3$ \\
\hline \multicolumn{6}{|l|}{ CAV3 } \\
\hline Aug 07 & $20.5 \pm 0.4$ & $6.3 \pm 0.2$ & $0.38 \pm 0.26$ & $0.00 \pm 0.00$ & nd \\
\hline Nov 07 & $28.0 \pm 0.4$ & $9.5 \pm 0.1$ & $0.91 \pm 0.22$ & $0.01 \pm 0.00$ & $25.9 \pm 0.3$ \\
\hline Jan 08 & $8.7 \pm 0.4$ & $1.7 \pm 0.1$ & $0.16 \pm 0.09$ & $-0.21 \pm 0.01$ & $27.5 \pm 1.7$ \\
\hline Apr 08 & $15.1 \pm 0.4$ & $3.8 \pm 0.0$ & $0.33 \pm 0.04$ & $0.01 \pm 0.00$ & $29.5 \pm 1.9$ \\
\hline
\end{tabular}

The presence of measurable amounts of $\mathrm{NO}_{3}{ }^{-}, \mathrm{NO}_{2}{ }^{-}$and $\mathrm{NH}_{4}{ }^{+}$in the slurries at the end of the incubations confirmed that there had been no substrate limitation (data not shown). Denitrification potentials varied spatially, with higher magnitudes observed in the upper estuary

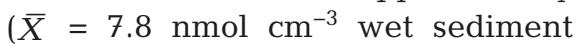
$\left.\mathrm{h}^{-1}, \mathrm{CAV} 3\right)$ and lower values being found in the lower estuary $(\bar{X}=4.6$ $\mathrm{nmol} \mathrm{cm} \mathrm{cm}^{-3}$ wet sediment $\mathrm{h}^{-1}, \mathrm{CAV} 1$; Fig. 2) (ANOVA, p < 0.05). However, denitrification at all sites and seasons was not linearly correlated with salinity, suggesting that salinity did not have a clear regulatory effect on the denitrification process in Cávado estuary. Moreover, no statistical relationship $(\mathrm{p}>0.05)$ existed between denitrification potential and any of the measured environmental variables.

Potential anammox activities in the Cávado River estuarine sediments ranged from 0 to $3.34 \mathrm{nmol} \mathrm{N} \mathrm{cm}^{-3} \mathrm{~h}^{-1}$ (Fig. 2). No significant spatial variations were found ( $p>0.05)$; however, clear minima in anammox activity occurred in summer, when higher temperatures were measured. A scatter plot of incubation temperature and anammox data (Fig. 3a) indicates that anammox
Denitrification and anammox activities were measured in sediment slurries under anoxic conditions and during short $(6 \mathrm{~h})$ incubations to ensure ${ }^{29 / 30} \mathrm{~N}_{2}$ concentration maxima during incubations.

\section{Potential anammox and denitrification activities}




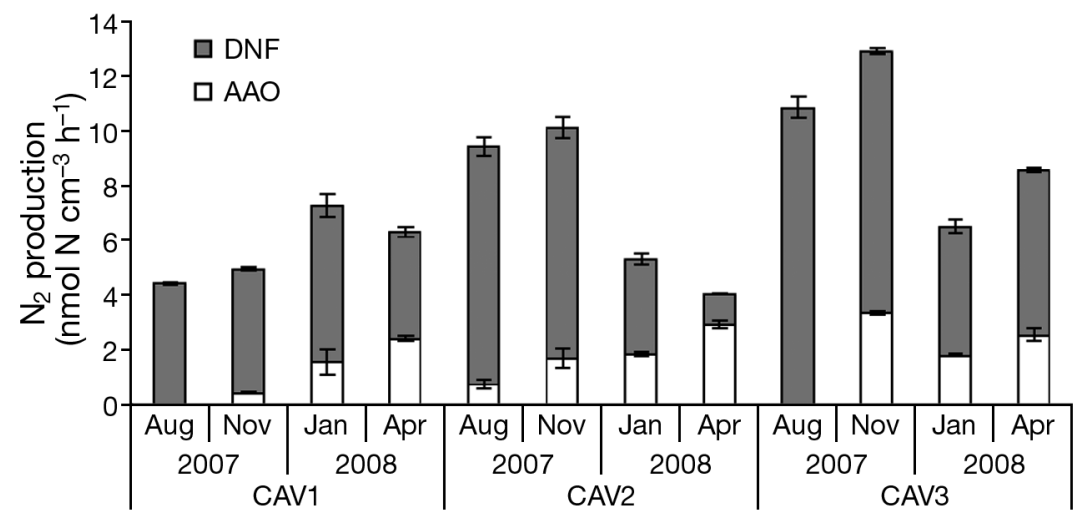

Fig. 2. Anammox (AAO) and denitrification (DNF) activities as determined from ${ }^{15} \mathrm{NO}_{3}{ }^{-}$-amended slurry incubations. Error bars represent $\mathrm{SE}$ of the mean $(\mathrm{n}=3)$ umn was revealed from the positive and linear correlation between these 2 variables $(\mathrm{r}=0.75, \mathrm{p}<0.05, \mathrm{n}=12$; Fig. 3b).

The relative contribution of anammox to dinitrogen production (ra) was as high as $72 \%$, observed in April at CAV2 (Table 2), with annual averages of 17,33 and $21 \%$ for sites CAV1, CAV2 and CAV3, respectively. TN and pore-water $\mathrm{NO}_{3}{ }^{-}$concentration were positively correlated with ra $(\mathrm{r}=0.78$ and $\mathrm{r}=0.74$, respectively; $\mathrm{p}<0.05$, $\mathrm{n}=12$ ).

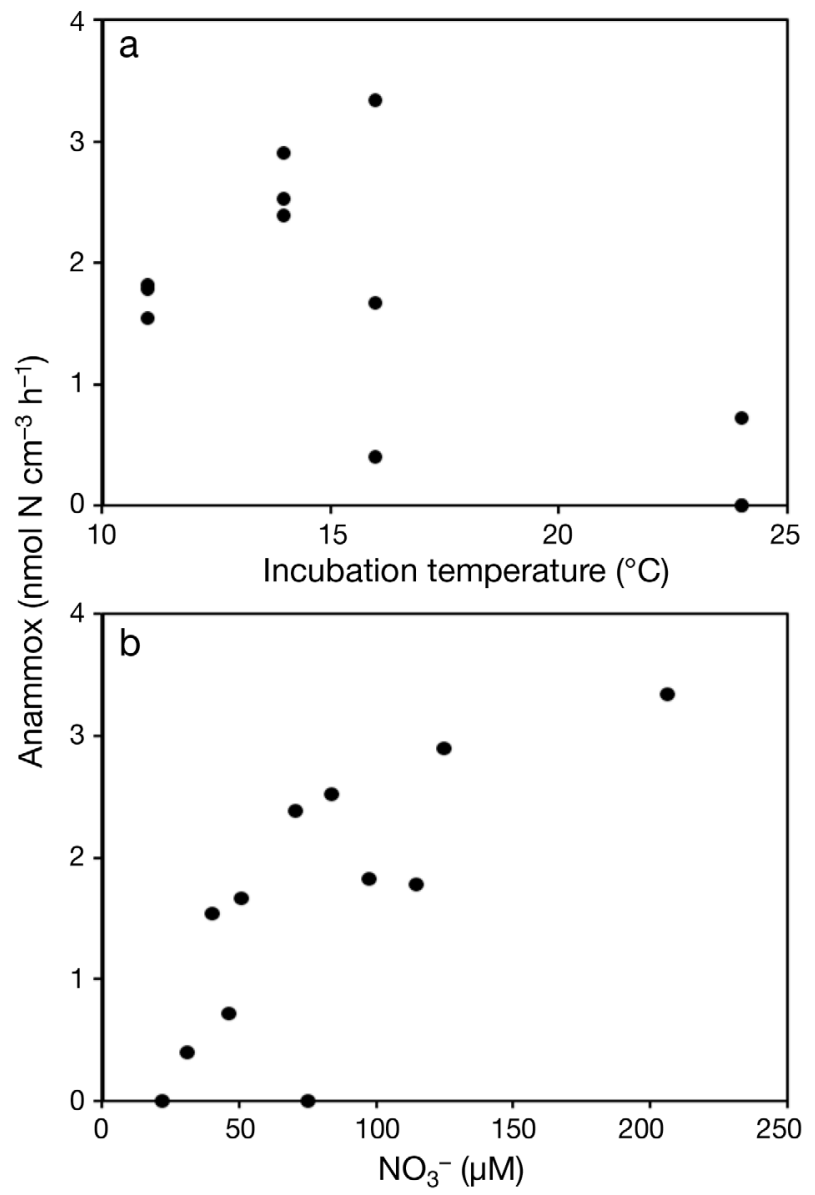

Fig. 3. Relationship between anammox activity and (a) incubation temperature, and (b) the concentration of nitrate in the water column

increased up to an optimum temperature (14 to $16^{\circ} \mathrm{C}$ ); activity tended to decrease after that. A progressive increase in potential anammox activity with the increase in availability of $\mathrm{NO}_{3}{ }^{-}$in the water col-

\section{Detection of anammox bacteria}

A nested PCR approach to amplify the anammoxspecific 16S rRNA gene was successful for CAV1 samples, in which anammox bacteria-related sequences were retrieved. The anammox sequences that we detected grouped within the genus Scalindua (Fig. 4). The clone $\mathrm{C} 113 \mathrm{~b}$ sequence was most similar $(99 \%)$ to the $16 \mathrm{~S}$ rRNA gene sequences retrieved from a hydrothermal vent located in the Guaymas basin, Mexico (Hirsch et al. 2011). Clone C12a sequence was most closely related (94\% sequence identity) to a sequence from Lake Rassnitzer, Germany (Hamersley et al. 2009). Clone C15b sequence shared $97 \%$ sequence similarities with Scalindua wagneri (Schmid et al. 2003). The remaining clones from the CAV1 site positioned phylogenetically between known anammox bacteria and non-anammox members of the Planctomycetes. The 16S rRNA gene sequences retrieved from CAV2 sediments were related to uncultured bacteria outside the planctomycete clade (Fig. 4). No DNA amplification was achieved from CAV3 samples with the molecular approach used.

\section{DISCUSSION}

Denitrification potential measured in the Cávado River varied along the estuary, although activity values did not correlate with salinity. Indeed, the activity of denitrifying bacteria is not influenced by the presence of sea salts (Magalhães et al. 2005a), suggesting that halotolerant denitrifying bacteria might inhabit these regions. Nitrate availability is frequently identified as an important environmental control for natural denitrification activity because 


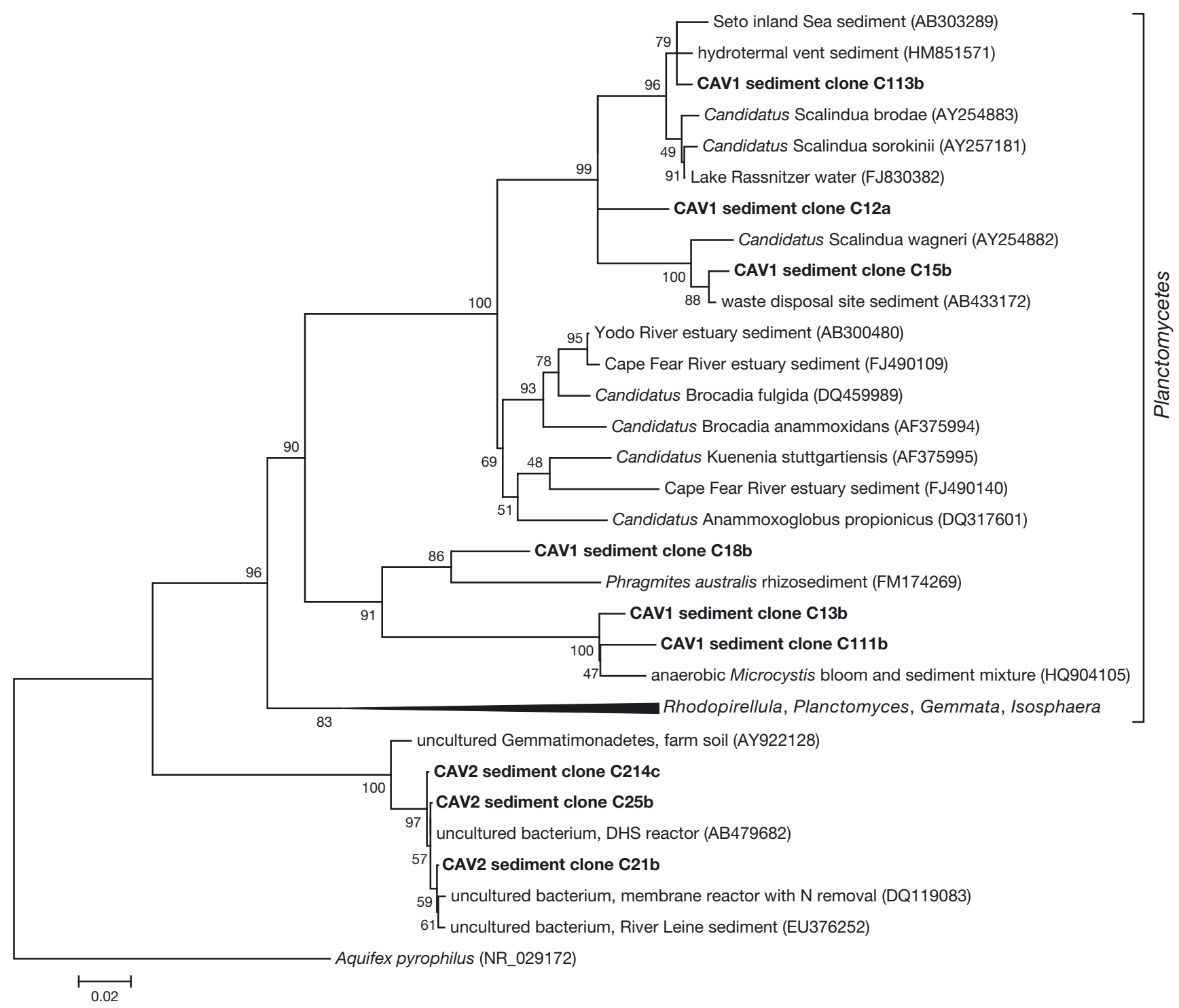

Fig. 4. Phylogenetic tree showing the affiliation of bacterial 16S rRNA gene sequences retrieved from the Cávado estuary in NW Portugal. The consensus tree is based on the neighbor-joining method; distance bootstrap values $>50 \%$ are indicated at branch points (1000 iterations). Aquifex pyrophilus (NR_029172) was used as an outgroup. Bacterial sequences from the Cávado estuary are depicted in bold and all other sequences are followed by their GenBank accession number in parentheses.

The scale bar represents $2 \%$ estimated sequence divergence

maximum denitrification rates usually occur when concentrations of $\mathrm{NO}_{3}{ }^{-}$in the water column are greatest (Ogilvie et al. 1997, Magalhães et al. 2005a,b). In the Cávado estuary, higher denitrification potentials were indeed measured at sites with higher concentrations of $\mathrm{NO}_{3}{ }^{-}$, although no significant relationship ( $p>0.05$ ) was found with any of the nitrogen species or environmental variables quantified. While spatial differences were observed in upper and lower estuarine locations (CAV1 and CAV3), no clear seasonal patterns of denitrification potential were detected (Fig. 2).
Potential anammox rates in the Cávado River estuary sediments ranged from 0 to $3.34 \mathrm{nmol} \mathrm{N} \mathrm{cm}{ }^{-3} \mathrm{~h}^{-1}$ (Fig. 2). Anammox activity was related positively to temperature up to intermediate temperatures of 14 to $16^{\circ} \mathrm{C}$, after which activity tended to decrease (Fig. 3a). Similarly, Rysgaard et al. (2004) referred to the anammox response as being psychrophilic after they observed an optimum temperature of $12^{\circ} \mathrm{C}$ for the activity of anammox bacteria in Arctic sediments. Futhermore, Dalsgaard \& Thamdrup (2002) reported a $15^{\circ} \mathrm{C}$ optimum in temperate shelf sediments. The anammox potentials reported here encompassed 12 
different samples from an annual survey, but the temperature optimum was very similar to those reported in single-sample temperature incubation experiments (Dalsgaard \& Thamdrup 2002, Rysgaard et al. 2004). Temperature was also described as a selective condition in an enrichment experiment of marine anammox bacteria (van de Vossenberg et al. 2008). The enriched cultures achieved rates similar to those of wastewater anammox bacteria, but at lower temperatures.

Our data also revealed a positive relationship between anammox and the concentration of $\mathrm{NO}_{3}{ }^{-}$in the water column. The importance of $\mathrm{NO}_{3}{ }^{-}$in regulating anammox has been additionally described in Rander Fjord (Risgaard-Petersen et al. 2004), where $\mathrm{NO}_{3}{ }^{-}$was abundant in the water column, as well as in other estuarine systems (e.g. Trimmer et al. 2003, Meyer et al. 2005, Rich et al. 2008) and in arctic marine sediments (Rysgaard et al. 2004). Meyer et al. (2005) showed a strong correlation between $\mathrm{NO}_{2}{ }^{-}$ production in sediments and anammox activity using microscale pore-water profiles. In estuarine sediments, the supply of $\mathrm{NO}_{2}{ }^{-}$via $\mathrm{NO}_{3}{ }^{-}$reduction linked to sediment reactivity (e.g. organic matter content) was suggested to regulate the contribution of anammox to total dinitrogen production (Trimmer et al. 2003, Nicholls \& Trimmer 2009). However, we observed no relationship between the content of organic matter and anammox activity in our study. The Cávado sediments were composed mainly of large-grain particles where oxic conditions are often present, suggesting that aerobic ammonium oxidation could also be a potential $\mathrm{NO}_{2}{ }^{-}$supplier to suboxic sediment layers. Indeed, Nielsen et al (2009) registered high rates of $\mathrm{NO}_{2}{ }^{-}$release predominantly associated with incomplete nitrification in sediments from the lower Weser estuary. Although these conditions might occur in situ, this hypothesis was not tested in our experiments - which were performed in anoxic slurry incubations that limit the aerobic oxidation of ammonium. Nonetheless, the relationship we found between the concentration of $\mathrm{NO}_{3}{ }^{-}$in the water column and anammox activity suggests that anammox bacteria are fuelled by $\mathrm{NO}_{2}^{-}$produced through a $\mathrm{NO}_{3}{ }^{-}$-reduction process.

While $\mathrm{NO}_{3}{ }^{-}$concentrations correlated well with salinity, we observed no variation in anammox activity along the salinity gradient, contrary to reports for other estuaries where anammox decreased seawards (Trimmer et al. 2003, Rich et al. 2008). Regarding the second anammox substrate, ammonium, a relationship between $\mathrm{NH}_{4}{ }^{+}$and anammox is not usually detected because this nutrient is seldom limiting in sediments (Dalsgaard et al. 2005).

The percentage contribution of anammox to total production of dinitrogen $(\mathrm{ra}$ ) was similar to the values documented previously in shelf sediments (Table 3), but was relatively high when compared to studies in shallow coastal $(<10 \mathrm{~m})$ and estuarine sediments (e.g. Thamdrup \& Dalsgaard 2002, Nicholls \& Trimmer 2009); these latter studies reported anammox as a minor process. If anything, the significance of the anammox reaction is probably underestimated, and the ra could be about 5 to $17 \%$ higher because our measurements were made in sediment slurries rather than from intact cores (Trimmer et al. 2006). On the other hand, anoxic conditions for anammox to occur might not always be present in Cávado estuarine sediments, altering the relative importance of the denitrification and anammox processes in the removal of nitrogen from this system.

Table 3. Potential anammox rates $\left(\mathrm{nmol} \mathrm{cm} \mathrm{cm}^{-3} \mathrm{~h}^{-1}\right)$ and the contribution of anammox to the production of dinitrogen (ra \%) measured in coastal sediments

\begin{tabular}{|llcll|}
\hline Location & Type of sediment & Anammox & ra \% & Source \\
\hline Aarhus Bay & Subtidal $(0-2 \mathrm{~cm})$ & 3.5 & 2 & Thamdrup \& Dalsgaard (2002) \\
Skagerrak & Subtidal $(0-2 \mathrm{~cm})$ & $1.3-4.1$ & $24-67$ & \\
Thames estuary & Intertidal $(0-2 \mathrm{~cm})$ & $0.2-9.8$ & $<1-8$ & Trimmer et al. (2003) \\
Arctic marine sediments & Subtidal $(0-4 \mathrm{~cm})$ & $0.2-15$ & $1-35$ & Rysgaard et al. (2004) \\
Randers Fjord & Intertidal $(0-0.5 \mathrm{~cm})$ & $3.8-11$ & $5-26$ & Risgaard-Petersen et al. (2004) \\
Logan River, Australia & Mangrove sediment & $0.5-8$ & $0-9$ & Meyer et al. (2005) \\
Skagerrak & Subtidal $(0-2 \mathrm{~cm})$ & $0.55-3.5$ & $15-79$ & Engström et al. (2005) \\
Long Island Sound & Subtidal $(0-2 \mathrm{~cm})$ & $0.91-1.2$ & $4-7$ & \\
Yodo estuary, Japan & Intertidal $(0-2)$ & $0.29-0.69^{\text {a }}$ & & Amano et al. (2007) \\
Chesapeake Bay & Subtidal & & $0-22$ & Rich et al. (2008) \\
Cape Fear Estuary & Subtidal $(0-3 \mathrm{~cm})$ & & $3.8-16.5$ & Dale et al. (2009) \\
Nine estuaries, SE England & Intertidal $(0-2 \mathrm{~cm})$ & & $<1-11$ & Nicholls \& Trimmer (2009) \\
Cávado estuary, NW Portugal & Intertidal $(0-5 \mathrm{~cm})$ & $0-3.34$ & $0-72$ & Present study \\
ancubation with ${ }^{15} \mathrm{NH}_{4}{ }^{+}$ & & & & \\
\hline
\end{tabular}


Taken together, our results suggest that the anammox process is probably modulated by only a few variables - which might explain the biogeographic stability in the magnitude of anammox activity in different regions (Table 3). Anammox potential rates in the Cávado River estuary sediments (0 to $3.34 \mathrm{nmol} N$ $\mathrm{cm}^{-3} \mathrm{~h}^{-1}$ ) were within the range reported for other sediments, such as temperate estuaries and coastal marine sediments (Table 3). Interestingly, as previously suggested (Meyer et al. 2005), such a parallel is usually not found for denitrification rates, whose magnitudes generally differ by several orders of magnitude between different natural ecosystems (e.g. Trimmer et al. 2003, Risgaard-Petersen et al. 2004, Dalsgaard et al. 2005). The variability in denitrification rates is consequently reflected in high variability in the relative importance of anammox to the total production of dinitrogen.

\section{CONCLUSIONS}

- The contribution of anammox to the overall production of dinitrogen found in this study was within the high range of values previously reported for other estuarine systems.

- Water column temperature and nitrate concentration were identified as important regulators of anammox activity in the Cávado estuary. These findings strengthen the role of these variables as prime environmental controls of the anammox process.

- These results reinforce the importance of the anammox reaction in removing fixed nitrogen from estuarine systems.

Acknowledgements. We thank A. Machado, W. Porubsky and $\mathrm{M}$. Bowles for their laboratory assistance. The Portuguese Foundation for Science and Technology (FCT) supported this research through a scholarship to C.T. (POCTI/CTA/39034/2001), a postdoctonal fellowship to C.M. (PTDC/MAR/098914/2008) and a grant to C.M. (PTDC/MAR/098914/2008).

\section{LITERATURE CITED}

Altschul SF, Gish W, Miller W, Myers EW, Lipman DJ (1990) Basic local alignment search tool. J Mol Biol 215:403-410

> Amano T, Yoshinaga I, Okada K, Yamagishi T and others (2007) Detection of anammox activity and diversity of anammox bacteria-related 16S rRNA genes in coastal marine sediment in Japan. Microbes Environ 22:232-242

Christensen PB, Nielsen LP, Sørensen J, Revsbech NP (1990) Denitrification in nitrate-rich streams: diurnal and seasonal variation related to benthic oxygen metabolism. Limnol Oceanogr 35:640-652
Cornwell JF, Kemp WM, Kana TM (1999) Denitrification in coastal ecosystems: methods, and ecosystem level controls, a review. Aquat Ecol 33:41-54

> Dale OR, Tobias CR, Song B (2009) Biogeographical distribution of diverse anaerobic ammonium oxidizing (anammox) bacteria in Cape Fear River Estuary. Environ Microbiol 11:1194-1207

Dalsgaard T, Thamdrup B (2002) Factors controlling anaerobic ammonium oxidation with nitrite in marine sediments. Appl Environ Microbiol 68:3802-3808

Dalsgaard T, Canfield DE, Petersen J, Thamdrup B, AcuñaGonzález J (2003) $\mathrm{N}_{2}$ production by the anammox reaction in the anoxic water column of Golfo Dulce, Costa Rica. Nature 422:606-608

> Dalsgaard T, Thamdrup B, Canfield DE (2005) Anaerobic ammonium oxidation (anammox) in the marine environment. Res Microbiol 156:457-464

> Dong LF, Smith CJ, Papaspyrou S, Stott A, Osborn AM, Nedwell DB (2009) Changes in benthic denitrification, nitrate ammonification, and anammox process rates and nitrate and nitrite reductase gene abundances along an estuarine nutrient gradient (the Colne estuary, United Kingdom). Appl Environ Microbiol 75:3171-3179

Engström P, Dalsgaard T, Hulth S, Aller RC (2005) Anaerobic ammonium oxidation by nitirite (anammox): implications for $\mathrm{N}_{2}$ production in coastal marine sediments. Geochim Cosmochim Acta 69:2057-2065

> Eyre BD, Rysgaard S, Dalsgaard T, Christensen PB (2002) Comparison of isotope pairing and $\mathrm{N}_{2}$ :Ar methods for measuring sediment denitrification-assumptions, modifications, and implications. Estuaries 25(6A):1077-1087

$>$ Fulweiler RW, Nixon SW, Buckley BA, Granger SL (2007) Reversal of the net dinitrogen gas flux in coastal marine sediments. Nature 448:180-182

Galloway JN, Aber JD, Erisman JW, Seitzinger SP, Howarth RW, Cowling EB, Cosby BJ (2003) The nitrogen cascade. BioScience 53:341-356

> Galloway JN, Townsend AR, Erisman JW, Bekunda M and others (2008) Transformation of the nitrogen cycle: recent trends, questions, and potential solutions. Science 320:889-892

Grasshoff K, Ehrhardt M, Kremling K (eds) (1983) Methods of seawater analysis, 2nd edn. Verlag Chemie, Weinheim

Gruber N, Galloway JN (2008) An Earth-system perspective of the global nitrogen cycle. Nature 451:293-296

Hall TA (1999) BioEdit: a user-friendly biological sequence alignment editor and analysis program for Windows 95/98/NT. Nucleic Acids Symp Ser 41:95-98

Hamersley MR, Woebken D, Boehrer B, Schultze M, Lavik G, Kuypers MMM (2009) Water column anammox and denitrification in a temperate permanently stratified lake (Lake Rassnitzer, Germany). Syst Appl Microbiol 32: 571-582

Hamm RE, Thompson TG (1941) Dissolved nitrogen in the sea water of the Northeast Pacific with notes on the total carbon dioxide and the dissolved oxygen. J Mar Res 4: $11-27$

> Herbert RA (1999) Nitrogen cycling in coastal marine ecosystems. FEMS Microbiol Rev 23:563-590

> Hirsch MD, Long ZT, Song B (2011) Anammox bacterial diversity in various aquatic ecosystems based on the detection of hydrazine oxidase genes (hzoA/hzoB). Microb Ecol 61:264-276

INAG (2010). Portuguese Water Institute. http://snirh. inag.pt (accessed July 2010) 
Jensen MM, Petersen J, Dalsgaard T, Thamdrup B (2009) Pathways, rates, and regulation of $\mathrm{N}_{2}$ production in the chemocline of an anoxic basin, Mariager Fjord, Denmark. Mar Chem 113:102-113

Jones MN (1984) Nitrate reduction by shaking with cadmium: alternative to cadmium columns. Water Res 18:643-646

Kana TM, Darkangelo C, Hunt MD, Oldham JB, Bennett GE, Cornwell JC (1994) Membrane inlet mass spectrometer for rapid high-precision determination of $\mathrm{N}_{2}, \mathrm{O}_{2}$ and $\mathrm{Ar}$ in environmental water samples. Anal Chem 66:4166-4170

Kuypers MMM, Lavik G, Woebken D, Schmid M and others (2005) Massive nitrogen loss from the Benguella upwelling system through anaerobic ammonium oxidation. Proc Natl Acad Sci USA 102:6478-6483

Lam P, Lavik G, Jensen MM, van de Vossenberg J and others (2009) Revising the nitrogen cycle in the Peruvian oxygen minimum zone. Proc Natl Acad Sci USA 106:4752-4757

Magalhães CM, Joye SB, Moreira R, Wiebe WJ, Bordalo AA (2005a) Effect of salinity and inorganic nitrogen concentrations on nitrification and denitrification rates in intertidal sediments and rocky biofilms of the Douro River estuary, Portugal. Water Res 39:1783-1794

Magalhães CM, Wiebe WJ, Joye SB, Bordalo AA (2005b) Inorganic nitrogen dynamics in intertidal rocky biofilms and sediments of the Douro River estuary (Portugal). Estuaries 28:592-606

Magalhães C, Teixeira C, Teixeira R, Machado A, Azevedo I, Bordalo AA (2008) Dissolved organic carbon and nitrogen dynamics in the Douro River estuary, Portugal. Cienc Mar 34:271-282

Meyer RL, Risgaard-Petersen N, Allen DE (2005) Correlation between anammox activity and microscale distribution of nitrite in a subtropical mangrove sediment. Appl Environ Microbiol 71:6142-6149

Mulder A, van de Graaf AA, Robertson LA, Kuenen JG (1995) Anaerobic ammonium oxidation discovered in a denitrifying fluidized bed reactor. FEMS Microbiol Ecol 16:177-184

Muyzer G, de Waal EC, Uitterlinder AG (1993) Profiling of complex microbial populations by denaturing gradient gel electrophoresis analysis of polymerase chain reaction-amplified genes coding for 16S rRNA. Appl Environ Microbiol 59:695-700

Neef A, Amann RI, Schlesner H, Schleifer KH (1998) Monitoring a widespread bacterial group: in situ detection of planctomycetes with 16S rRNA-targeted probes. Microbiology 144:3257-3266

Nicholls JC, Trimmer M (2009) Widespread occurrence of the anammox reaction in estuarine sediments. Aquat Microb Ecol 55:105-113

Nielsen M, Gieseke A, de Beer D, Revsbech NP (2009) Nitrate, nitrite, and nitrous oxide transformations in sediments along a salinity gradient in the Weser Estuary. Aquat Microb Ecol 55:39-52

Nixon SW (1981) Remineralization and nutrient cycling in coastal marine ecosystems. In: Neilson BJ, Cronin LE (eds) Estuaries and nutrients. Humana Press, Clifton, NJ

Ogilvie B, Nedwell DB, Harrison RM, Robinson A, Sage A (1997) High nitrate, muddy estuaries as nitrogen sinks: The nitrogen budget of the River Colne estuary (United Kingdom). Mar Ecol Prog Ser 150:217-228

Percival JB, Lindsay PJ (1997) Measurement of physical properties of sediments. In: Mudroch A, Azcue JM,
Mudroch P (eds) Manual of physico-chemical analysis of Aquatic sediments. CRC Press, Boca Raton, FL, p 7-45

Rich JJ, Dale OR, Song B, Ward BB (2008) Anaerobic ammonium oxidation (anammox) in Chesapeake Bay sediments. Microb Ecol 55:311-320

Risgaard-Petersen N, Meyer RL, Schmid M, Jetten MSM, Enrich-Prast A, Rysgaard S, Revsbech NP (2004) Anaerobic ammonium oxidation in an estuarine sediment. Aquat Microb Ecol 36:293-304

$>$ Rysgaard S, Christensen PB, Nielsen LP (1995) Seasonal variation in nitrification and denitrification in estuarine sediment colonized by benthic microalgae and bioturbating infauna. Mar Ecol Prog Ser 126:111-121

> Rysgaard S, Glud RN, Risgaard-Petersen N, Dalsgaard T (2004) Denitrification and anammox activity in Arctic marine sediments. Limnol Oceanogr 49:1493-1502

- Schmid M, Twachtmann U, Klein M, Strous M and others (2000) Molecular evidence for genus level diversity of bacteria capable of catalyzing anaerobic ammonium oxidation. Syst Appl Microbiol 23:93-106

Schmid M, Walsh K, Webb R, Rijpstra WIC and others (2003) Candidatus 'Scalindua brodae', sp. nov., Candidatus 'Scalindua wagneri,' sp. nov., two new species of anaerobic ammonium oxidizing bacteria. Syst Appl Microbiol 26:529-538

Seitzinger S, Harrison JA, Bohlke JK, Bouwman AF and others (2006) Denitrification across landscapes and waterscapes: a synthesis. Ecol Appl 16:2064-2090

Strous M, Fuerst JA, Kramer EHM, Logemann S and others (1999) Missing lithotroph identified as a new planctomycete. Nature 400:446-449

- Tamura K, Peterson D, Peterson N, Stecher G, Nei M, Kumar S (2011) MEGA5: Molecular evolutionary genetics analysis using maximum likelihood, evolutionary distance, and maximum parsimony methods. Mol Biol Evol 28: 2731-2739

- Thamdrup B, Dalsgaard T (2002) Production of $\mathrm{N}_{2}$ through anaerobic ammonium oxidation coupled to nitrate reduction in marine sediments. Appl Environ Microbiol 68: $1312-1318$

- Thompson JD, Higgins DG, Gibson TJ (1994) Clustal W: Improving the sensitivity of progressive multiple sequence alignment through sequence weighting, position-specific gap penalties and weight matrix choice. Nucleic Acids Res 22:4673-4680

Trimmer M, Nicholls JC, Deflandre B (2003) Anaerobic ammonium oxidation measured in sediments along the Thames estuary, United Kingdom. Appl Environ Microbiol 69:6447-6454

Trimmer M, Risgaard-Petersen N, Nicholls JC, Engström P (2006) Direct measurement of anaerobic ammonium oxidation (anammox) and denitrification in intact sediment cores. Mar Ecol Prog Ser 326:37-47

van de Graaf AA, Mulder A, de Bruijn P, Jetten MSM, Robertson LA, Kuenen JG (1995) Anaerobic oxidation of ammonium is a biologically mediated process. Appl Environ Microbiol 61:1246-1251

> van de Vossenberg J, Rattray JE, Geerts WJC, Kartal B and others (2008) Enrichment and characterization of marine anammox bacteria associated with global nitrogen gas production. Environ Microbiol 10:3120-3129

van Luijn F, Boers PCM, Lijklema L, Sweerts JPRA (1999) Nitrogen fluxes and processes in sandy and muddy sediments from a shallow eutrophic lake. Water Res 33:33-42 